\title{
Plant Vascular Tissues-Connecting Tissue Comes in All Shapes
}

\author{
Eva Hellmann ${ }^{1, \dagger}$, Donghwi Ko ${ }^{1, \dagger}$, Raili Ruonala ${ }^{1,2, \dagger}$ and Ykä Helariutta ${ }^{1,2, *}$ \\ 1 The Sainsbury Laboratory, University of Cambridge, Cambridge CB2 1LR, UK; \\ eva.hellmann@slcu.cam.ac.uk (E.H.); donghwi.ko@slcu.cam.ac.uk (D.K.); \\ raili.ruonala@slcu.cam.ac.uk (R.R.); \\ 2 Institute of Biotechnology, Department of Biological and Environmental Sciences, University of Helsinki, \\ FI-00014 Helsinki, Finland \\ * Correspondence: yrjo.helariutta@slcu.cam.ac.uk (Y.H.) \\ + These authors contributed equally to this work
}

Received: 2 November 2018; Accepted: 7 December 2018; Published: 13 December 2018

\begin{abstract}
For centuries, humans have grown and used structures based on vascular tissues in plants. One could imagine that life would have developed differently without wood as a resource for building material, paper, heating energy, or fuel and without edible tubers as a food source. In this review, we will summarise the status of research on Arabidopsis thaliana vascular development and subsequently focus on how this knowledge has been applied and expanded in research on the wood of trees and storage organs of crop plants. We will conclude with an outlook on interesting open questions and exciting new research opportunities in this growing and important field.
\end{abstract}

Keywords: Vasculature; Organogenesis; Development

\section{Vasculature and Its Arrangement}

In the 19th century, the variety of vascular arrangements in form of different stele types attracted the interest of researchers. From their analyses, they could conclude that different forms of steles can specialize in supporting different functions and their different shapes are specific for plant groups, enabling them to draw phylogenetic connections between groups [1]. Even within one plant, various stele types occur. The different stele types vary not only with developmental stages, but also within different mature organs such as leaves, stem, hypocotyl, and roots. Although the structures in different species and organs are of diverse build, they share some of the underlying regulatory mechanisms and their main functions for the plant. Generally, they enable plants to transport water, nutrients, assimilates, as well as signalling molecules, and provide stability to the plant body.

In this short review, we will focus on Arabidopsis thaliana as an example of an herbaceous species and as a commonly used model plant, in which many of the regulatory pathways for vascular development and arrangement have been elucidated. Furthermore, we will look at angiosperm trees, as they are a model for economically important wood production and tubers, which are essential agronomical food sources all over the world. As many processes underlying wood and tuber formation are shared, research on vascular development in Arabidopsis has and will inspire discoveries and development in economically and agronomically important vascular structures. Research on vascular development and expansion involving various species and growth forms is an excellent example of how basic research and applied research can work hand in hand to promote the growth of scientific knowledge and its application. 


\section{Vascular Development in Arabidopsis thaliana}

Vascular development in Arabidopsis thaliana has been a topic of intensive research for decades. Basic principles of vascular development in roots, hypocotyl, leaves, and stems have been elucidated and gene regulatory networks have been inferred. In the following chapters, we will introduce the primary and secondary development of Arabidopsis thaliana root, hypocotyl, and stems, with its main regulators, and subsequently look at wood development and tuber formation.

\subsection{Vascular Development in the Root}

Arabidopsis root vascular development initiates during embryogenesis. Provascular tissue is specified by a spatially and temporally confined auxin maximum established by the PIN-FORMED (PIN) auxin transport function (Figure 1) [2,3]. MONOPTEROS (MP) expression, which marks future veins, is induced by auxin [4-7] and provides feedback on the auxin status by promoting PIN1 expression [5,8-10]. Another component of auxin signalling, BODENLOS (BDL), was found to regulate TAGRET OF MONOPTEROS (TMO) 3, 5, 6, and 7 upwards [10], which proved to be essential for proper MP function [11]. The MP-TMO5-LONESOME HIGHWAY (LHW) module, regulating cell division in the whole plant, was also found to play a role in the definition of the provasculature $[8,11,12]$. Among other factors, cytokinin is important for provascular development. The TMO5-LHW module induces cytokinin biosynthesis via activation of LONELY GUY (LOG) genes [13] and the cytokinin transporter PURINE PERMEASE 14 (PUP14) is required for early vascular development [14].

The postembryonic root vasculature in Arabidopsis consists of a xylem strand that is surrounded by procambial cells and two opposing phloem poles. Layers of pericycle and endodermis enclose the vascular cylinder (Figure 2A). As is the case during embryogenesis, auxin and cytokinin play a major role in postembryonic development (Figure 3). Cytokinin reporters are expressed in the procambium, whereas auxin reporters mark the xylem cells $[15,16]$. The dominant negative cytokinin receptor mutant wooden leg (wol) shows a reduced number of vascular cell files and all inner cell types differentiate into protoxylem $[17,18]$. The lack of all three receptor kinases for cytokinin perception leads to a similar phenotype [19] as does the overexpression of a cytokinin degrading enzyme of the CYTOKININE OXIDASE (CKX) family [20,21]. The inhibitor of cytokinin signalling ARABIDOPSIS HISTDINE PHOSPHOTRANSFER PROTEIN 6 (AHP6) plays an important role in protoxylem differentiation [20]. It is upregulated by auxin and is a major component of the mutual inhibitory cytokinin-auxin feedback loop regulating procambium maintenance versus xylem differentiation [22]. Another interconnection between auxin and cytokinin regulation is the TMO5-LHW pathway. In postembryonic development, the TMO5-LHW dimer is, as in provascular development, induced by auxin via MP and activates cytokinin biosynthesis via upregulation of LOG genes [13]. Aside from auxin and cytokinin, phytohormone jasmonic acid has also been shown to regulate xylem development. An increase of jasmonic acid levels leads to extra xylem vessels, but this is abolished in jasmonic acid receptor mutants. Jasmonic acid function in vessel development is linked to cytokinin signalling via regulation of $A H P 6$ by the jasmonic acid regulated transcription factor MYC2 [23]. Further regulators of xylem differentiation include HD-ZIP IIIs that promote metaxylem development [24] and are regulated via the SHORTROOT (SHR)-SCARECROW (SCR) pathway $[25,26]$ via the levels of the inhibitory miRNAs mi165/166 [24,27]. The metaxylem cell fate is also characterised by the expression of the thermospermine biosynthesis gene ACAULIS 5 (ACL5) $[28,29]$. Thermospermine regulates the translation of the SUPRESSOR OF ACAULIS LIKE (SACL) protein family, which then affects the TMO5-LHW interaction that acts on xylem differentiation and cytokinin biosynthesis [12,13,30-33]. 


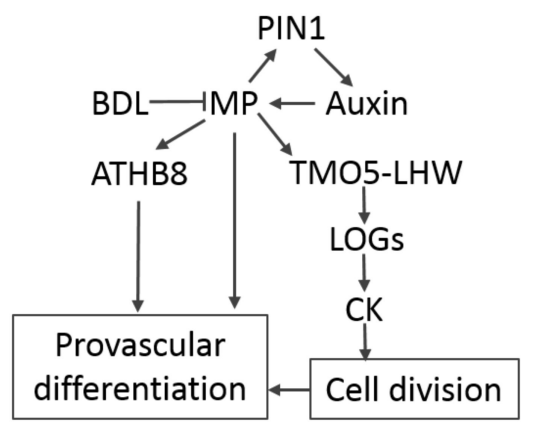

Provascular differentiation

Figure 1. Arabidopsis provascular differentiation. MONOPTEROS (MP) is a central regulator in provascular development. It is induced by auxin and promotes auxin flow by induction of PIN-FORMED (PINs). MP function is also modified by BODENLOS (BDL). MP enhances ATHB8 expression, which contributes to provascular differentiation. It also regulates the TAGRET OF MONOPTEROS 5 (TMO5)-LONESOME HIGHWAY (LHW) dimer, which activates CK (cytokinin) biosynthesis and promotes cell division. LOG-LONELY GUY.

(A)

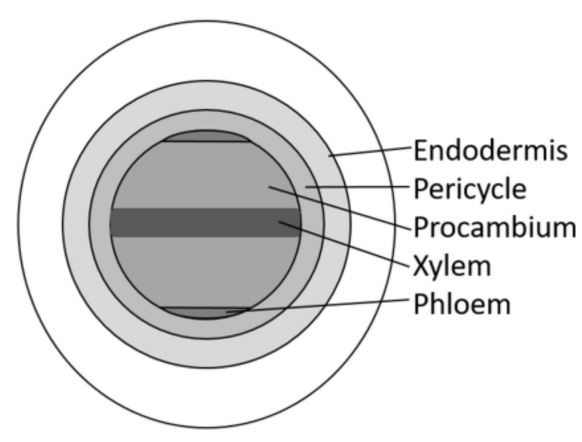

Vascular cylinder primary root (dicot)
(B)

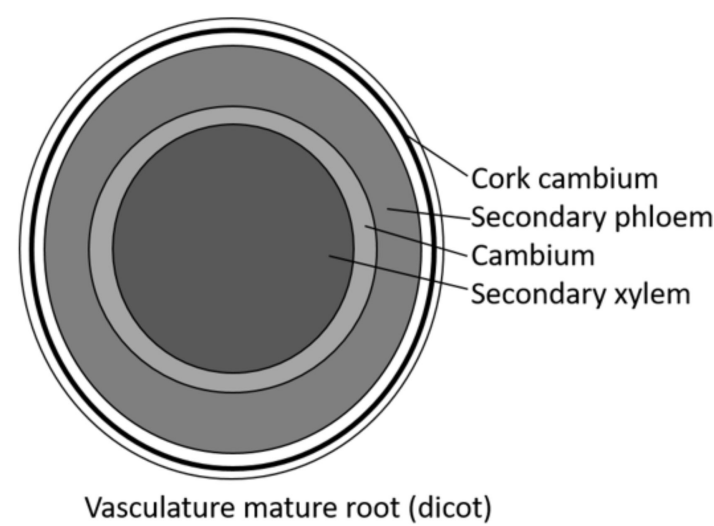

Figure 2. Schematic cross-sections of a primary root (A) and a mature root with secondary growth (B). In the primary root, two phloem poles are separated by procambium surrounding the central xylem axis. Around this structure, a ring of pericycle cells and endodermis cells can be found (A). In roots that have gone through secondary growth, there is a central secondary xylem cylinder surrounded by a continuous cambium and a ring of secondary phloem. Further out, a cork cambium can serve as a lateral meristem giving rise to cork and phelloderm (B). 


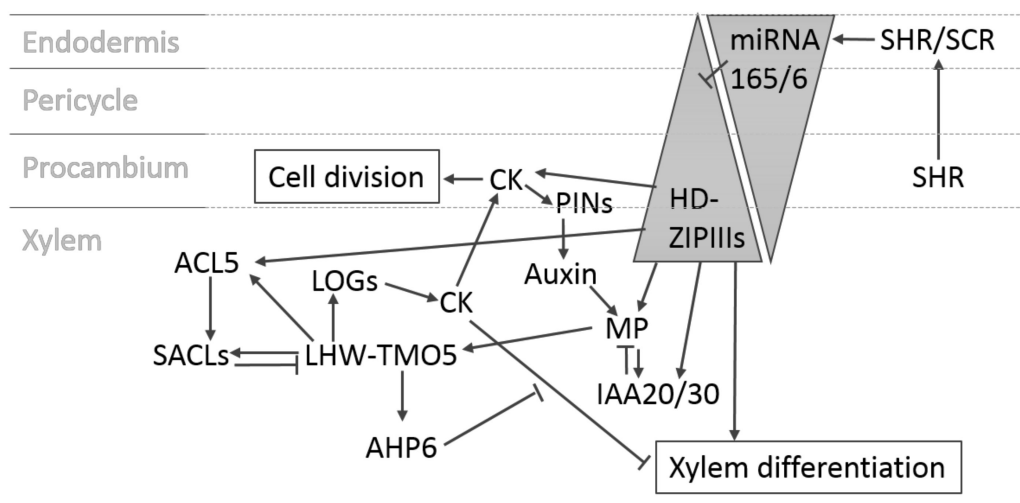

Xylem differentiation

Figure 3. Xylem differentiation in the primary root. HD-ZIP IIIs are important promotors of xylem differentiation. Their level is regulated by a gradient of inhibitory miRNA165/6. miRNA165/6 levels are defined by SHORTROOT (SHR)/SCARECROW (SCR) dimer presence. The gradient is established by SHR diffusion from its production area in the procambium to the endodermis, where it forms the dimer with SCR that promotes miRNA165/6 expression. This results in a miRNA165/6 gradient with highest levels in the endodermis and an inverse gradient for HD-ZIP IIIs that promote xylem differentiation. The HD-ZIP IIIs induce MP and IAA20/30. They also enhance ACL5 expression and CK (cytokinin) production. ACL5 induces translation of SUPRESSOR OF ACAULIS LIKE (SACL) genes that inhibit LHW-TMO5 dimerization and thus LOG expression, lowering the CK levels. The dimer also induces the CK signalling inhibitor $A H P 6$, inhibiting the negative effect of CK on xylem differentiation. In the procambium, the CK inhibitory effects mediated by the HD-ZIP IIIs are not present, which leads to higher CK levels and signalling, resulting in cell division rather than xylem differentiation. CK induces PIN activity, pumping auxin out of the procambium. This causes an auxin maximum in the xylem axis, which subsequently induces $M P$ expression.

Protophloem differentiation in Arabidopsis thaliana is dependent on the OCTOPUS (OPS)-BRASSINOSTEROID INSENSITIVE 2 (BIN2)-BRASSINOSTEROID INSENSITIVE 1 (BIN1) cascade, on COTYLEDON VASCULAR PATTERN 2 (CVP2), and on the BREVIS RADIX (BRX)-BARELY ANY MERISTEM 3 (BAM3)-CLVATA3/ESR-related (CLE45) module. OPS represses BIN2 [34,35]. BRX acts in a similar way and restricts BAM3 expression confining CLE45 perception spatially [36,37]. Recently, other receptors for the CLE peptides have been identified that act independently of CORYNE (CRN)-CLAVATA 2 (CLV2). CLE-RESISTANT RECEPTOR KINASE (CLERK) and its homologues SENESCENCE-ASSOCIATED RECEPTOR-LIKE KINASE (SARK) and NSP-INTERACTING KINASE 1 (NIK1) represent a new module for CLE sensing in protophloem development $[38,39]$. The CLE45 signal was shown to be enhanced by MEMBRANE-ASSOCIATED KINASE REGULATOR 5 (MAKR5) action [40]. For sieve element differentiation, SUPPRESSOR OF MAX1-LIKE (SMXL) 3, 4, and 5 are required [41]. In contrast to the regulation of procambium proliferation and xylem differentiation, not cytokinin or auxin, but brassinosteroids are the most influential phytohormones for phloem differentiation [40,42,43]. Protophloem sieve element development is modulated by interaction with BRX and PROTEIN KINASE ASSOCIATED WITH BRX (PAX) with PIN1. Whereas BRX inhibits PIN1 mediated auxin efflux, PAX enhances it, leading to a balanced and ordered regulation of auxin distribution that is necessary for protophloem development [44].

ALTERED PHLOEM DEVELOPMENT (APL) regulates phloem differentiation [45,46]. NO APICAL MERISTEM, ATAF, CUP-SHAPED COTYLEDON (NACs), and NAC45/86-DEPENDENT EXONUCLEASE-DOMAIN PROTEINs (NENs) are involved in phloem maturation, which culminates in enucleation and the presence of fully developed sieve pores [47]. Furthermore, NAC20 was found to negatively regulate APL in phloem development [48]. 
Secondary growth in herbaceous dicotyledonous species such as Arabidopsis is characterised by the build-up of secondary cell walls in the xylem and lateral growth via a continuous cambium. These events are prominent in the Arabidopsis stem and hypocotyl, which are discussed next.

\subsection{Vascular Development in Shoot and Hypocotyl}

The elongation of the Arabidopsis inflorescence stem (bolting) coincides with the transition from the vegetative to the reproductive stage. The primary shoot apical meristem is committed to producing flowers and the rib meristem is activated to push the newly forming flowers upwards from the vegetative rosette. The molecular mechanisms regulating the primary vascular patterning in the extending tip of the young stem are poorly understood [49]. The stem vasculature is organized in separate bundles that eventually become connected by a so-called interfascicular cambium [50]. In the basal part of the stem, in the vicinity of the rosette, the activity of the interfascicular cambium results in complete cylindrical rings of the vascular tissues: phloem, cambium, and xylem, one inside another. Like the primary vascular organization in the Arabidopsis root described in the previous section, the Arabidopsis hypocotyl (embryonic stem) develops a xylem axis in the centre of the stele and two phloem poles, which are intervened by procambial cells, during the primary growth [51,52]. Common molecular factors modulate the primary vascular development in the root and the hypocotyl. Mutants defected in the primary vascular patterning in the root also exhibit similar flaws in the hypocotyl vasculature. For instance, $M P$ and $W O L$ are expressed in the root and the hypocotyl vascular tissues during embryogenesis and post-embryonic development, and the mutants are impaired in the vascular patterning of both organs $[6,18,53]$. In contrast to the Arabidopsis root, which has been a representative system to study the primary growth, the Arabidopsis hypocotyl and inflorescence stem have been useful model systems to scrutinize the molecular processes underlying secondary growth [52,54,55]. Especially, the hypocotyl undergoes substantial secondary thickening by the activity of vascular cambium and cork cambium, similar to wood formation in trees. The hypocotyl does not grow longitudinally during secondary growth, which makes it easier to observe the progression of radial thickening in a time-dependent manner [52,56,57]. Indeed, multiple molecular components such as phytohormones, transcription factors, peptides, and receptors, orchestrating the secondary growth in the Arabidopsis hypocotyls and the inflorescence stem, have been characterised [52,54,55]. In this section, we will mainly introduce the signalling networks underlying the secondary development in the hypocotyl and the inflorescence stem.

The radial secondary growth of the hypocotyl starts after the cambium forms and can be divided into two distinct phases, characterised by the xylem expansion accompanied by a fibre differentiation [56-58]. In phase I, the early phase, xylem vessel elements emerge and the surrounding cells remain as xylem parenchyma cells [56]. Similarly, during the early phase in the phloem, sieve elements, companion cells and parenchyma cells differentiated, but not fibres [52]. The expansion rates of the two conducting tissues are comparable in the early stage; thereby leaving the proportions of xylem and phloem to the total transverse area of the hypocotyls roughly constant $[57,58]$. In contrast, in phase II, parenchyma cells in the xylem and the phloem differentiate into xylem or phloem fibres with thick secondary cell walls, providing mechanical strength to the plants. The xylem area expands faster than the phloem, which leads to a higher ratio of xylem to phloem, like wood [56-58] (Figure 2B). According to studies done by Ragni and co-workers [59], the transition from phase I to II in hypocotyls concurs with the development of the inflorescence stem (conversion from vegetative to reproductive growth) in various rosette plants including Arabidopsis thaliana, Cardamine hirsute, Barberea verna, and Taraxacum officinalis $[57,59]$. However, this seems to be characteristic to rosette plants as the non-rosette plants (Arabis alpine, Aster alpinus, Nicotiana benthamiana, and Solanum lycopersicum) examined undergo the xylem expansion during vegetative growth [59]. Ragni et al. also found that xylem expansion is not regulated by floral specification, bolting, or age of the plants, but by gibberellin (GA), a phytohormone that is produced in the shoot upon flowering induction [59]. The detailed molecular mechanism underlying the GA signalling-mediated fibre differentiation remains to be 
unveiled, but recently, it was reported that the GA increases the expression of NAC SECONDARY WALL THICKENING PROMOTING FACTOR 1 (NST1) and NST3, the master transcription factors implicated in secondary cell wall thickening of xylem fibres [51,60]. They are homologous to the VND6 and VND7 factors, which are sufficient to guide secondary cell wall formation during xylem vessel formation [61]. In addition, it was shown that the leucine-rich receptor-like kinases (LRR-RLKs) ERECTA (ER) and its paralogue ER-LIKE1 (ERL1) prevent the premature GA-induced fibre differentiation in Arabidopsis hypocotyls upon the floral transition by suppressing the expression of NST1 and NST3 [51]. Not only GA-induced xylem fibre differentiation, but also the suppression of the two NSTs by ER and ERL1 are largely dependent on the class I KNOTTED1-like homeobox (KNOX) transcription factor 1 (KNAT1)/BREVIPEDICELLUS (BP), which was previously shown to regulate xylem fibre differentiation in the inflorescence stem [51,62]. Furthermore, KNAT1/BP and another class I KNOX transcription factor, SHOOT MERISTEMLESS (STM), were shown to repress the transcription of BLADE-ON-PETIOLE 1 (BOP1) and BOP2. Both encode BTB/POZ domain and ankyrin repeat-containing proteins, which negatively regulate xylem fibre differentiation in the hypocotyl [63]. Recently, Aurora kinases were identified as additional regulators of vascular development. They inhibit xylem and phloem formation via the transcriptional regulation of ALTERED PHLOEM DEVELOPMENT (APL), VASCULAR-RELATED NAC-DOMAIN 6 (VND6), and VND7 [64].

In addition to the genetic interactions implicated in fibre differentiation, a few other transcription factors involved in the cambial activity in hypocotyls and stems have been identified (Figure 4). For instance, WUSHEL-related HOMEOBOX 4 (WOX4) and WOX14 are upregulated by the CLE41/44/TRACHEARY ELEMENT DIFFERENTIATION INHIBITORY FACTOR (TDIF) (peptide ligands)-PHLOEM INTERCALATED WITH XYLEM (PXY)/TDIF RECEPTOR (TDR) (LRR-RLK) module in the cambium and play a part in cambial proliferation [65-70]. In parallel to the CLE41/44/TDIF-PXY/TDR module, the signalling by the phytohormone ethylene facilitates cambial cell division by inducing ETHYLENE RESPONSE FACTORs (ERFs), such as ERF109, ERF018, and ERF1 [71]. It was suggested that the two signal cascades interact with each other via ethylene, inducing the expression of PXY/TDR but WOX4 suppressing ethylene signalling [71]. Two more receptor-like kinases, REDUCED IN LATERAL GROWTH1 (RUL1) and MORE LATERAL GROWTH1 (MOL1), are also involved in regulation of cambial activity [72,73]. There seem to be complex interactions between hormonal pathways, the LRR-RLKs and the transcription factors to fine-tune vascular development. For example, WOX4 is also shown to be upregulated by auxin and the induction is stabilized in a PXY/TDR-dependent manner [74]. Recently, it was reported that WOX14 is also involved in the xylem differentiation by inducing the expression of GA3-oxidase, which catalyses the production of bioactive GAs in the vascular bundle of the inflorescence stem [75]. Furthermore, in the stem, ER is shown to suppress the expression of PXY-LIKE 1 (PXL1) and PXL2, while PXY, PXL1, PXL2, and ER upregulate the expression of ERL1 and ERL2 [76]. Interestingly, the interactions in the hypocotyl are distinct from those in the stem. In the hypocotyl, PXY, PXL1, PXL2, and ER repress the expression of ERL1 and ERL2 [76].

Furthermore, other phytohormones, such as auxin, cytokinin, strigolactone, and jasmonic acid, positively regulate cambial activity [77-79] and the interactions between key regulators during the secondary growth were recently analysed by network modelling [80]. Recently, the molecular interactions between auxin, cytokinin, and PXY signalling have been elucidated. Han and co-workers demonstrated that the CLE41/44/TDIF-PXY/TDR module regulates cambial proliferation by inhibiting BIN2-LIKE 1 (BIL1). BIL1 phosphorylates MP, which, upon phosphorylation, enhances the expression of ARABIDOPSIS RESPONSE REGULATOR (ARR) 7 and 15, resulting in suppression of cambial activity [81]. Moreover, it was reported that auxin signalling in the Arabidopsis inflorescence stem not only promotes cambial activity by inducing AUXIN RESPONSE FACTOR (ARF) 3 and 4 expression outside of the stem cell domain in the cambium, but also facilitates xylem differentiation of cambial cells through MP suppression of WOX4 activity and direct activation of xylem-related genes [82]. Interestingly, WOX4 expression is not altered in the bill mutant, suggesting that the 
suppression of WOX4 by MP would be independent of the BIL1-mediated phosphorylation [81]. In addition to promoting the cambial proliferation, the CLE41/44/TDIF-PXY/TDR module also represses xylem differentiation of cambial cells by stimulating the activity of BIN2. BIN2 inhibits BRI1-EMS-SUPPRESSOR (BES1), a downstream transcription factor of brassinosteroid signalling [83]. Not much is known about upstream acting factors, but it was shown that KANADI genes, GARP family transcription factors, negatively regulate cambial activity by disrupting expression and polar localization of PIN1 [84]. More recently, a novel regulator involved in phloem differentiation has been characterised. The zinc-finger RNA-binding protein JULGI binds to the 5' UTR of SMXL4/5 mRNA, inhibiting their translation and suppressing phloem development [85].

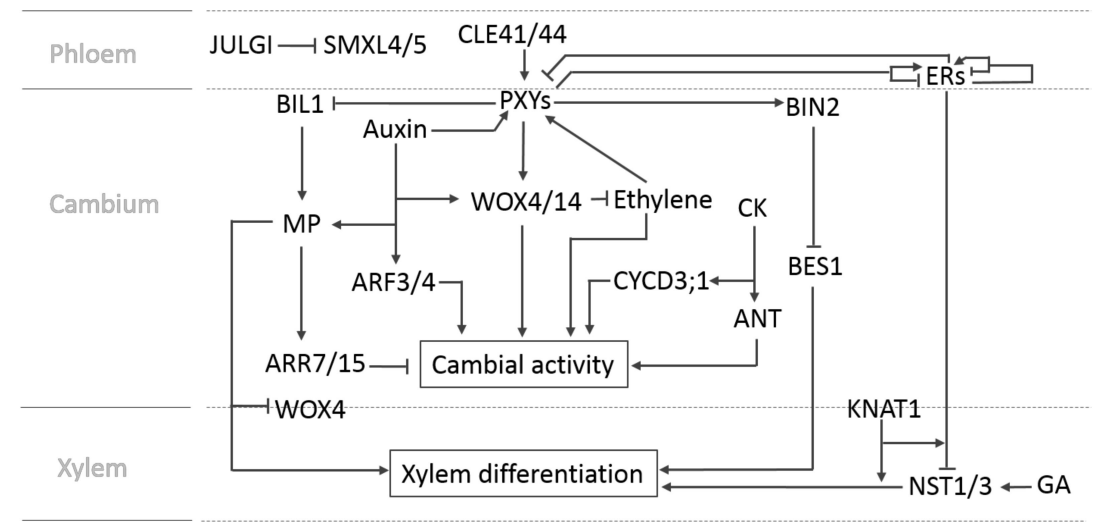

Xylem differentiation in secondary growth

Figure 4. CLAVATA3/ESR-related (CLE)41/44/TRACHEARY ELEMENT DIFFERENTIATION INHIBITORY FACTOR (TDIF) generated in the phloem is perceived by the cambium-localised PHLOEM INTERCALATED WITH XYLEM (PXY)/TDIF RECEPTOR (TDR), which induces expression of WUSCHEL-related HOMEOBOX (WOX)4/14 and activates BRASSINOSTEROID INSENSITIVE 2 (BIN2). WOX4/14 promotes cambial activity and BIN2 inhibits BRI1-EMS-SUPPRESSOR (BES1), which facilitates xylem differentiation. In addition, the CLE41/44/TDIF-PXY/TDR module enhances cambial activity by suppressing BIN2-LIKE 1 (BIL1)-mediated phosphorylation of MP that induces $A R R 7 / 15$ inhibition of cambial activity. The positive role of the auxin on cambium activity involves PXY and WOX4. In addition, auxin signalling upregulates the expression of ARF3 and ARF4 outside of the stem cell domain in the cambium, which facilitates the cambial proliferation. $M P$ is induced by auxin and contributes to xylem differentiation via repressing WOX4 but activating xylem-related genes in the cambium. Ethylene induces the expression of $P X Y$ and ERF109, ERF018, and ERF1, which enhances the cambial activity. WOX4 suppresses ethylene signalling. Cytokinin upregulates the expression of the D-type cyclin CYCD3;1 and AINTEGUMENTA (ANT) to enhance cambial activity [86]. Gibberellin (GA) signalling facilitates xylem fibre differentiation by elevating the expression of NST1 and NST3 in a KNAT1/BP-dependent manner. In contrast, ERECTA (ER) and ER-LIKE1 (ERL1) inhibit the expression of NST1 and NST3 in a KNAT1 / BP-dependent manner and suppress xylem differentiation. The two families of leucine-rich receptor-like kinases (LRR-RLKs), PXYs (PXY, PXL1, PXL2) and ERs (ER, ERL1, ERL2), mutually regulate their expressions. In the stem, ER suppresses the expression of PXL1 and PXL2, whereas PXYs and ER upregulate the expression of ERL1 and ERL2. However, in the hypocotyl, PXYs and ER repress the expression of ERL1 and ERL2. Please note that we describe ER in the phloem section of the figure for simplicity, but it was shown that ER is expressed in the epidermis, phloem, and xylem of inflorescence stems [87], and ER and ERL1 are expressed in the stele of hypocotyls [51]. JULGI, which is expressed in the phloem and cambium, inhibits translation of SUPPRESSOR OF MAX1-LIKE (SMXL)4/5 by binding to the 5' UTR of their mRNAs, and thereby suppresses phloem differentiation. 


\section{Agronomically Important Structures Derived from Plant Vasculatures}

As summarised above, a substantial amount of knowledge has been gained by examining vascular development in Arabidopsis. In the next two sections, we will focus on how this knowledge can and has been applied to agronomically important plants, especially to wood producing trees, and to species that produce edible tubers as storage organs. On the other hand, research in these fields has provided new insight that is feeding back into research on Arabidopsis.

\subsection{Wood Development-Secondary Growth of Trees}

Spontaneously, one might not consider Arabidopsis, a small inconspicuous weed, to be beneficial for studies on secondary growth. However, at a miniature scale, many developmental events found in Arabidopsis can mimic the same principal features that are landmarks for trees, even down to a molecular level. One such event characteristic of trees is the extensive formation of woody tissues in the trunk. A multitude of factors, for example, cytokinin, auxin, gibberellin and ethylene, HD-ZIP IIIs, as well as the PXY-CLE41/44 signalling pathway and its target WOX4, have been shown to influence secondary growth in trees [88-95] in a manner similar to Arabidopsis. These aspects have been extensively reviewed (e.g., [96-98]; also, see above). In this section, we provide an overview of wood (secondary xylem) characteristics in angiosperm trees, and highlight some recent advances in this research field.

Secondary growth relies on closely coordinated cell division in the meristematic zone (the cambium); subsequent expansion; secondary cell wall development; and, in some cases, programmed cell death, all of which finally result in differentiated daughter cells serving their function. In a tree trunk during the active growth season, the cambial zone is composed of several layers of thin-walled cells that appear alike in histological cross-sections (Figure 5A). Recently, Bossinger et al. [99] performed an interesting somatic sector analysis in the Populus stem, suggesting the existence of a single cell layer of cambial initials, thought of as stem cells, that can divide in both anticlinal and periclinal orientations, and independently give rise to xylem or phloem. With their system, the authors succeeded in visualizing cell fate during wood development deep inside the trunk over the course of several months, providing insight into the cambial dynamics in a mature tree trunk. Another recently reported toolkit that may be expected to advance our understanding of wood development is the protein-protein and protein-DNA interactome, covering a set of genes expressed in the secondary tissues of Populus trunk $[100,101]$. On top of the high-resolution transcriptomics, hormonal profiling, and proteomics data accumulating from Populus ([102-105]), this adds to the growing body of resources available from this prominent tree model species.

Cambium produces secondary xylem, wood, towards the pith of the stem. Wood appears heterogeneous in a sense that it is composed of several cell types with a variable size and function, however, the majority of them are hollow and heavily lignified when mature ([107]). Besides lignin, cellulose and hemicellulose are major components of the secondary cell wall $[108,109]$. Such solid structures are necessary to support the weight of the plant tissues, including various substances within these tissues, as well as to provide protection against parasites and bacteria. The water-conducting cells are commonly known as tracheary elements (vessels and tracheids). Of these, vessels are the primary conduits for long-distance water transport in the angiosperm wood, while tracheids are predominant in gymnosperms. Typically, vessel elements are decorated by secondary cell wall thickenings and connected at their ends by perforated cell plates to allow a continuum throughout the plant. Vessels are outstanding by terms of a large diameter when compared with any other xylem cell type, which contributes to high efficiency in water transport. On the other hand, the width of the vessels increases the risk of embolism induced by freeze-thaw cycling at temperate regions or during drought (see [110]). Correlations between embolism resistance and lignin contents of wood have been indicated, suggesting that both the herbaceous, including Arabidopsis, and tree species with a high lignin content are more resistant to embolism [111,112]. Factors underlying the spatial patterning 
of vessels, or any other cell type, within the wood are poorly understood, however, a recent report suggests a role for basipetal auxin transport in Populus vessel distribution [113].
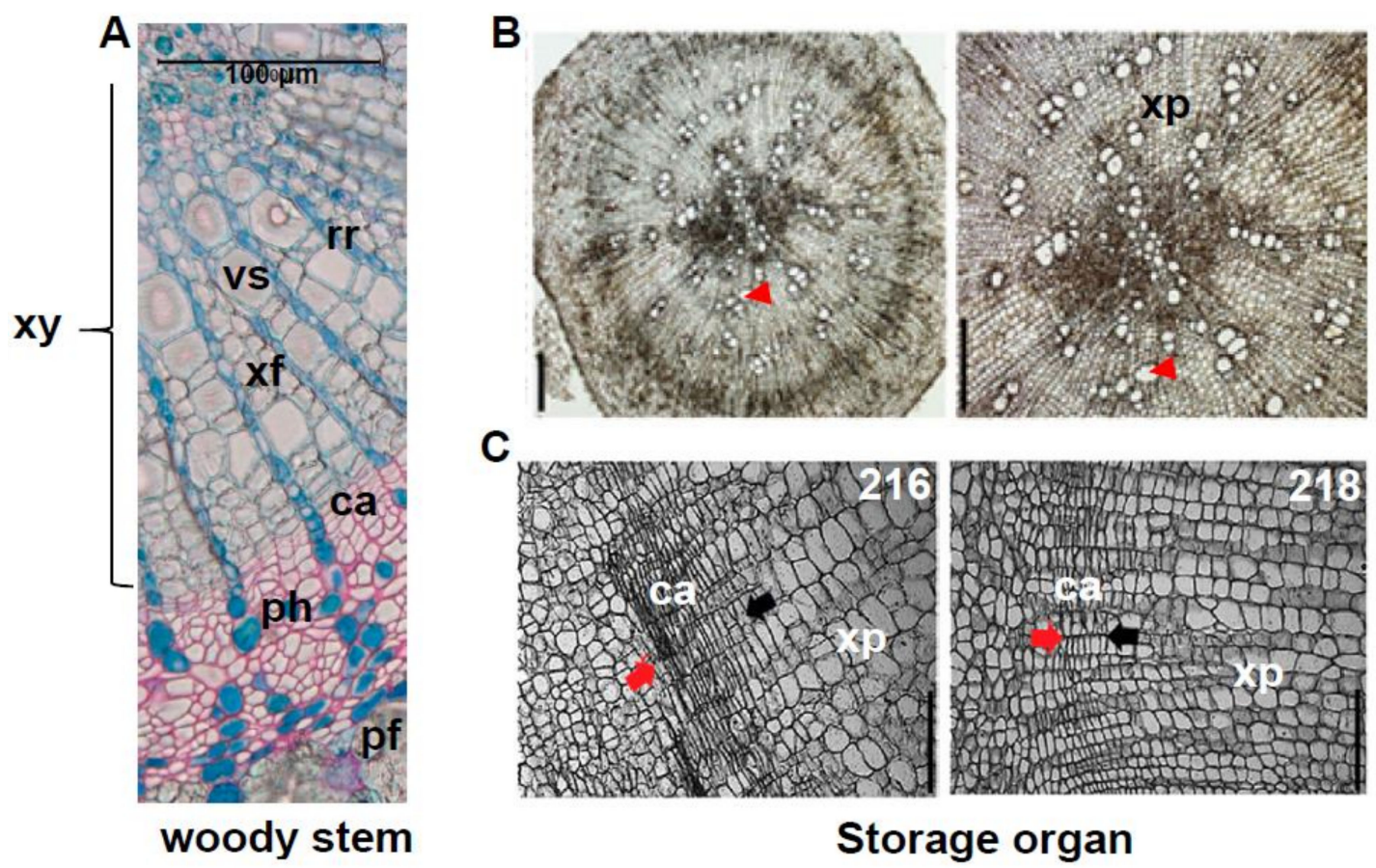

Figure 5. Cross-sections of birch (Betula pendula) stem (A) and storage organs of radish (Raphanus sativus) (B,C). Angiosperm wood is composed of xylem fibres and vessels to a large extent (A), while there is a substantial number of xylem parenchyma cells in the radish of three-week-old line 216 (B). The red arrow head indicates one of the xylem vessel cells. The size bar is $200 \mu \mathrm{m}(\mathbf{B})$. The line 216 (left), which generates the larger storage organ, harbours a wider cambial zone when compared with the line 218 (right). Cambium zones are marked by red and black arrows with the red arrows on the side of the cortex region. The size bar is $100 \mu \mathrm{m}(\mathbf{C})$. Abbreviations: xy-xylem; vs-vessel; xf—xylem fibre; rr—radial ray; ca-cambium; ph—phloem; $\mathrm{pf}$-phloem fibre; $x p$-xylem parenchyma. (A) By courtesy of Chang Su, University of Helsinki; (B) and (C) adapted with permission from Jang et al. (2015) [106] and http://www.biologists.com/journal-of-experimental-biology/ doi:10.1093/jxb/erv220.

In addition to the vessels, wood contains two other cell types: fibres and parenchyma. The thick-walled fibres constitute the bulk, up to $80 \%$ of the angiosperm wood (commonly named hardwood) volume [110] and provide mechanical support to the plant. In Arabidopsis, xylem fibres are found in all organs undergoing secondary growth upon induction of flowering. The hormonal and molecular basis of vessel and fibre differentiation processes has been studied extensively in various plant systems such as Arabidopsis and Populus, and important discoveries regarding secondary cell wall formation and programmed cell death have also arisen from Zinnia and Arabidopsis suspension cell culture systems. In previous sections, we discussed some factors involved in fibre and vessel differentiation, however, further perspectives on this topic are provided in a number of recent reviews (e.g., $[107,108])$. While the vessels and fibres are programmed to die, the xylem parenchyma remain as living cells. In trees, parenchyma cells form rays that facilitate radial transport of water and solutes across the vascular tissues. Furthermore, rays function in carbohydrate storage and protection from embolism within the xylem [114]. As the secondary growth in Arabidopsis is limited, rays apparently do not develop spontaneously and seem to represent a rare aspect of wood development that, in addition to seasonality, requires a long-living woody species for functional studies. However, formation of ray-like cells has been reported in Arabidopsis stems, where secondary growth was induced under 
weight stress [115], further highlighting the amenable nature of this little weed for a wide array of manipulations.

It is notable that wood is porous yet stiff, and typically requires drying as well as chemical processing prior to use as a construction material or pulp [116]. Wood processing methods are constantly optimized; for example, Song et al. [117] reported a compression method that, in combination with a carefully designed chemical treatment to partially remove lignin and hemicellulose, increased wood stiffness and strength by an impressive factor of 11 . The authors were able to increase the strength of the cellulose component and, in fact, modify the wood structure and composition such that one might draw an imaginary analogue to tension wood (dried and flattened to an extreme). In nature, tension wood develops in the upper side of a tree branch or as a result of bending, to support the weight of the leaning structure. When compared with normal wood, tension wood appears more compact with smaller cell sizes. Furthermore, the cellulose content is higher and the mechanical strength is increased in this special type of angiosperm wood. Various phytohormones, including auxin, gibberellin and ethylene, have been implicated in the formation of tension wood-like features and transcriptomics analyses in Populus have shed light on the molecular control of this phenomenon (reviewed by Groover [118]). In the next sections, we move on to different types of special structures, edible storage organs, which, however, are also composed of vascular tissues.

\subsection{Tubers-Edible Storage Organs}

Various plant species have evolved secondary growth mechanisms specialized to produce storage organs composed of many parenchyma cells that accumulate photosynthates in the form of sucrose or starch. For instance, Raphanus sativus (radish), Brassica rapa (turnip), Daucus carota (carrot), and Beta vulgaris (sugar beet) generate storage organs (tubers) from their taproots. Manihot esculenta (cassava) and Ipomoea batatas (sweet potato) produce them from their fibrous roots and Solanum tuberosum (potato) forms tubers from stolons, underground stems [119-123]. The formation of tubers occurs when plants are exposed to the certain conditions, like short days, or when they reach a certain age, and they start to enlarge dramatically upon their initiation [119,123-125]. The initiation of potato tuberisation has been well characterised and has been reviewed [119]. Here, we mainly focus on the bulking stage of storage organs and putative approaches to enhance the secondary growth via modulation of the underlying signalling pathways.

The transverse structure of tubers varies but as a common feature they possess a high number of parenchyma cells for storage [106,126-131] (Figure 5B,C). To generate such structure during organogenesis, high cambial activity is needed to increment the number of cells and inhibit the differentiation of the parenchyma cells to the xylem fibres at the same time. This suggests that engineering tubers to reinforce cambial activity and to sustain the cells as parenchyma cells could increase the capacity and/or size of the storage organs. For this, knowledge about xylem differentiation in Arabidopsis secondary growth is of great value. One approach to improve cambial activity in the storage organs could be to engineer cytokinin biogenesis or signalling as cytokinins are crucial for cambial activity. Similarly, the CLE41/44/TDIF-PXY/TDR module and WOX4/14 transcription factors play a crucial part in the cambial activity and could be manipulated to enhance cell proliferation. GA is one of the key factors inducing xylem fibre differentiation. Inhibiting GA signalling or the downstream transcription factors, such as NST1 and NST3, could prevent xylem fibre differentiation of parenchyma cells and contribute to increasing storage capacity. Indeed, there are a few studies showing that storage organs development involves molecular components similar to modulators of Arabidopsis secondary development. Jang and co-workers showed that in a radish inbred line development of a larger storage organ correlates with stronger cambial activities and higher cytokinin responses in the cambium [106]. They demonstrated that exogenous cytokinin treatment can result in a substantial increase in cell proliferation in the cambium zone and overall secondary growth in a dose-dependent manner, suggesting that cytokinin signalling and responses are crucial for the secondary thickening of radish [106]. In addition, cytokinin signalling seems to be important 
for the initiation of tuberisation as the overexpression a cytokinin biosynthesis gene in tomato or exogenous cytokinin application together with sucrose of potato lead to the storage organ formation from their axillary buds [119,132]. Gancheva and co-workers showed that the transcripts of RsCLE41, the AtCLE41 homologue, is primarily expressed in the cambium and the phloem of the radish. Interestingly, its expression in Raphanus sativus is much higher than in the presumably ancestral Raphanus raphanistrum, that does not produce the enlarged taproot tubers [133]. Moreover, exogenous treatment or overexpression of RsCLE41 increases the number of meristematic foci in the centre of the secondary xylem and facilitates cell division in the regular cambium and the meristematic foci. This suggests that the RsCLE41-mediated signalling is involved in the secondary growth of radish as well as in Arabidopsis [133]. GA induces xylem fibre differentiation in Arabidopsis, so exogenous GA treatment might reduce the tuber productivity, whereas treatment with the GA biosynthesis inhibitor paclobutrazol (PBZ) might elevate it. Several studies examined the effect of exogenous GA and PBZ treatment on storage organ development and showed that GA-treated carrot and radish are inhibited in storage organ secondary thickening whereas PBZ-treated carrot, radish and potato exhibited enhanced thickening [131,134-136]. It was shown that the exogenous GA facilitates the xylem differentiation and increases the lignin content in the carrot [131]. In radish, it was shown that PBZ treatment increases the number of cells in the xylem area and the size of xylem vessels [135], suggesting that the suppression GA signalling can be used to increase storage organ productivity. In addition to applying knowledge gained from unravelling the networks regulating secondary growth in Arabidopsis, there have been approaches that characterize genome-wide transcriptomic changes during the tuberisation or comparisons between tuberous and non-tuberous roots to understand the bulking processes in the radish, cassava, and sweet potato $[120,125,128,137]$. Altogether, the application of those advances can contribute to progress in engineering or breeding to enhance tuber productivity.

\section{Future Perspectives}

Our current understanding of secondary growth provides fundamental knowledge to improve wood formation. On the basis of research on Arabidopsis secondary growth, engineering of wood formation in tree species has made great progress in the last decade (e.g., $[88,93,102])$. It is not yet known exactly how storage organs develop a substantial number of xylem parenchyma cells with high sugar or starch content. The Arabidopsis hypocotyl and its underlying regulatory network can be very informative for the examination of storage organ regulation and its engineering for higher productivity. A major question is how the switch between differentiation of fibres versus parenchyma cells is regulated in the hypocotyl of Arabidopsis, as well as in its Brassiceae relatives with storage root capacity. Insights into secondary growth regulation, storage root development in crops and in potentially new model species, the identification of potential targets for engineering in those, and the development of adjusted methods are particularly relevant, as crop species exhibiting storage roots are currently not compatible with intensive molecular genetics, thus hampering their genetic analysis and efficient bioengineering.

Author Contributions: E.H., D.K. and R.R. contributed equally to the manuscript. Y.H. supervised and edited the work. All authors wrote the manuscript and approved the draft.

Funding: Y.H. was supported by Finnish Centre of Excellence in Molecular Biology of Primary Producers (Academy of Finland CoE program 2014-2019) decision \#271832. Y.H.'s laboratory was funded by the Gatsby Foundation [GAT3395/PR3)]; the National Science Foundation Biotechnology and Biological Sciences Research Council grant [BB/N013158/1]; University of Helsinki [award 799992091], the European Research Council Advanced Investigator Grant SYMDEV [No. 323052]. D.K. was funded by an EMBO long-term fellowship ALTF 305-2017.

Acknowledgments: We thank Chang Su (University of Helsinki) for kindly providing an unpublished image of a birch stem section. The images of radish root sections were adapted with the permission of Ji-Young Lee (Seoul National University) and the publisher of the original article (Journal of Experimental Botany; [106]), for which we are thankful.

Conflicts of Interest: The authors declare no conflict of interest. 


\section{References}

1. De Bary, A.; Bower, F.O.; Scott, D.H. Comparative Anatomy of the Vegetative Organs of the Phanerogams and Ferns; Clarendon Press: Oxford, UK.

2. Steinmann, T.; Geldner, N.; Grebe, M.; Mangold, S.; Jackson, C.L.; Paris, S.; Gälweiler, L.; Palme, K.; Jürgens, G. Coordinated Polar Localization of Auxin Efflux Carrier PIN1 by GNOM ARF GEF. Science 1999, 286, 316. [CrossRef] [PubMed]

3. Friml, J.; Vieten, A.; Sauer, M.; Weijers, D.; Schwarz, H.; Hamann, T.; Offringa, R.; Jürgens, G. Efflux-dependent auxin gradients establish the apical-basal axis of Arabidopsis. Nature 2003, 426, 147-153. [CrossRef]

4. Mayer, U.; Ruiz, R.A.T.; Berleth, T.; Miséra, S.; Jürgens, G. Mutations affecting body organization in the Arabidopsis embryo. Nature 1991, 353, 402-407. [CrossRef]

5. Wenzel, C.L.; Schuetz, M.; Yu, Q.; Mattsson, J. Dynamics of MONOPTEROS and PIN-FORMED1 expression during leaf vein pattern formation in Arabidopsis thaliana. Plant J. 2007, 49, 387-398. [CrossRef] [PubMed]

6. Hardtke, C.S.; Berleth, T. The Arabidopsis gene MONOPTEROS encodes a transcription factor mediating embryo axis formation and vascular development. EMBO J. 1998, 17, 1405-1411. [CrossRef] [PubMed]

7. Berleth, T.; Jurgens, G. The role of the monopteros gene in organising the basal body region of the Arabidopsis embryo. Development 1993, 118.

8. Ohashi-Ito, K.; Matsukawa, M.; Fukuda, H. An Atypical bHLH Transcription Factor Regulates Early Xylem Development Downstream of Auxin. Plant Cell Physiol. 2013, 54, 398-405. [CrossRef]

9. Weijers, D.; Schlereth, A.; Ehrismann, J.S.; Schwank, G.; Kientz, M.; Jürgens, G. Auxin Triggers Transient Local Signaling for Cell Specification in Arabidopsis Embryogenesis. Dev. Cell 2006, 10, 265-270. [CrossRef]

10. Schlereth, A.; Möller, B.; Liu, W.; Kientz, M.; Flipse, J.; Rademacher, E.H.; Schmid, M.; Jürgens, G.; Weijers, D. MONOPTEROS controls embryonic root initiation by regulating a mobile transcription factor. Nature 2010, 464, 913-916. [CrossRef]

11. De Rybel, B.; Möller, B.; Yoshida, S.; Grabowicz, I.; Barbier de Reuille, P.; Boeren, S.; Smith, R.S.; Borst, J.W.; Weijers, D. A bHLH complex controls embryonic vascular tissue establishment and indeterminate growth in Arabidopsis. Dev. Cell 2013, 24, 426-437. [CrossRef]

12. Ohashi-Ito, K.; Saegusa, M.; Iwamoto, K.; Oda, Y.; Katayama, H.; Kojima, M.; Sakakibara, H.; Fukuda, H. A bHLH Complex Activates Vascular Cell Division via Cytokinin Action in Root Apical Meristem. Curr. Biol. 2014, 24, 2053-2058. [CrossRef] [PubMed]

13. De Rybel, B.; Adibi, M.; Breda, A.S.; Wendrich, J.R.; Smit, M.E.; Novák, O.; Yamaguchi, N.; Yoshida, S.; Van Isterdael, G.; Palovaara, J.; et al. Integration of growth and patterning during vascular tissue formation in Arabidopsis. Science 2014, 345, 1255215. [CrossRef] [PubMed]

14. Zürcher, E.; Liu, J.; di Donato, M.; Geisler, M.; Müller, B. Plant development regulated by cytokinin sinks. Science 2016, 353, 1027-1030. [CrossRef] [PubMed]

15. Bishopp, A.; Help, H.; El-Showk, S.; Weijers, D.; Scheres, B.; Friml, J.; Benková, E.; Mähönen, A.P.; Helariutta, Y. A Mutually Inhibitory Interaction between Auxin and Cytokinin Specifies Vascular Pattern in Roots. Curr. Biol. 2011, 21, 917-926. [CrossRef] [PubMed]

16. Müller, C.J.; Valdés, A.E.; Wang, G.; Ramachandran, P.; Beste, L.; Uddenberg, D.; Carlsbecker, A. PHABULOSA Mediates an Auxin Signaling Loop to Regulate Vascular Patterning in Arabidopsis. Plant Physiol. 2016, 170, 956-970. [CrossRef] [PubMed]

17. Scheres, B.; Di Laurenzio, L.; Willemsen, V.; Hauser, M.T.; Janmaat, K.; Weisbeek, P.; Benfey, P.N. Mutations affecting the radial organisation of the Arabidopsis root display specific defects throughout the embryonic axis. Development 1995, 121, 53-62.

18. Mähönen, A.P.; Bonke, M.; Kauppinen, L.; Riikonen, M.; Benfey, P.N.; Helariutta, Y. A novel two-component hybrid molecule regulates vascular morphogenesis of the Arabidopsis root. Genes Dev. 2000, 14, 2938-2943. [CrossRef]

19. Mähönen, A.P.; Higuchi, M.; Törmäkangas, K.; Miyawaki, K.; Pischke, M.S.; Sussman, M.R.; Helariutta, Y.; Kakimoto, T. Cytokinins Regulate a Bidirectional Phosphorelay Network in Arabidopsis. Curr. Biol. 2006, 16, 1116-1122. [CrossRef] 
20. Mähönen, A.P.; Bishopp, A.; Higuchi, M.; Nieminen, K.M.; Kinoshita, K.; Törmäkangas, K.; Ikeda, Y.; Oka, A.; Kakimoto, T.; Helariutta, Y. Cytokinin signaling and its inhibitor AHP6 regulate cell fate during vascular development. Science 2006, 311, 94-98. [CrossRef]

21. Werner, T.; Motyka, V.; Strnad, M.; Schmülling, T. Regulation of plant growth by cytokinin. Proc. Natl. Acad. Sci. USA 2001, 98, 10487-10492. [CrossRef]

22. Bishopp, A.; Lehesranta, S.; Vatén, A.; Help, H.; El-Showk, S.; Scheres, B.; Helariutta, K.; Mähönen, A.P.; Sakakibara, H.; Helariutta, Y. Phloem-transported cytokinin regulates polar auxin transport and maintains vascular pattern in the root meristem. Curr. Biol. 2011, 21, 927-932. [CrossRef] [PubMed]

23. Jang, G.; Chang, S.H.; Um, T.Y.; Lee, S.; Kim, J.-K.; Choi, Y. Do Antagonistic interaction between jasmonic acid and cytokinin in xylem development. Sci. Rep. 2017, 7, 10212. [CrossRef] [PubMed]

24. Carlsbecker, A.; Lee, J.-Y.; Roberts, C.J.; Dettmer, J.; Lehesranta, S.; Zhou, J.; Lindgren, O.; Moreno-Risueno, M.A.; Vatén, A.; et al. Cell signalling by microRNA165/ 6 directs gene dose-dependent root cell fate. Nature 2010, 465, 316-321. [CrossRef] [PubMed]

25. Helariutta, Y.; Fukaki, H.; Wysocka-Diller, J.; Nakajima, K.; Jung, J.; Sena, G.; Hauser, M.-T.; Benfey, P.N. The SHORT-ROOT Gene Controls Radial Patterning of the Arabidopsis Root through Radial Signaling. Cell 2000, 101, 555-567. [CrossRef]

26. Nakajima, K.; Sena, G.; Nawy, T.; Benfey, P.N. Intercellular movement of the putative transcription factor SHR in root patterning. Nature 2001, 413, 307-311. [CrossRef] [PubMed]

27. Muraro, D.; Mellor, N.; Pound, M.P.; Help, H.; Lucas, M.; Chopard, J.; Byrne, H.M.; Godin, C.; Hodgman, T.C.; King, J.R.; et al. Integration of hormonal signaling networks and mobile microRNAs is required for vascular patterning in Arabidopsis roots PLANT BIOLOGY. PNAS 2014, 111, 857-862. [CrossRef] [PubMed]

28. Muñiz, L.; Minguet, E.G.; Singh, S.K.; Pesquet, E.; Vera-Sirera, F.; Moreau-Courtois, C.L.; Carbonell, J.; Blázquez, M.A.; Tuominen, H. ACAULIS5 controls Arabidopsis xylem specification through the prevention of premature cell death. Development 2008, 135, 2573-2582. [CrossRef]

29. Yoshimoto, K.; Noutoshi, Y.; Hayashi, K.; Shirasu, K.; Takahashi, T.; Motose, H. Thermospermine suppresses auxin-inducible xylem differentiation in Arabidopsis thaliana. Plant Signal. Behav. 2012, 7, 937-939. [CrossRef]

30. Vera-Sirera, F.; Minguet, E.G.; Singh, S.K.; Ljung, K.; Tuominen, H.; Blázquez, M.A.; Carbonell, J. Role of polyamines in plant vascular development. Plant Physiol. Biochem. 2010, 48, 534-539. [CrossRef]

31. Katayama, H.; Iwamoto, K.; Kariya, Y.; Asakawa, T.; Kan, T.; Fukuda, H.; Ohashi-Ito, K. A Negative Feedback Loop Controlling bHLH Complexes Is Involved in Vascular Cell Division and Differentiation in the Root Apical Meristem. Curr. Biol. 2015, 25, 3144-3150. [CrossRef]

32. Yamamoto, M.; Takahashi, T. Thermospermine enhances translation of SAC51 and SACL1 in Arabidopsis. Plant Signal. Behav. 2017, 12, e1276685. [CrossRef] [PubMed]

33. Cai, Q.; Fukushima, H.; Yamamoto, M.; Ishii, N.; Sakamoto, T.; Kurata, T.; Motose, H.; Takahashi, T. The SAC51 Family Plays a Central Role in Thermospermine Responses in Arabidopsis. Plant Cell Physiol. 2016, 57, 1583-1592. [CrossRef] [PubMed]

34. Bauby, H.; Divol, F.; Truernit, E.; Grandjean, O.; Palauqui, J.-C. Protophloem Differentiation in Early Arabidopsis thaliana Development. Plant Cell Physiol. 2007, 48, 97-109. [CrossRef] [PubMed]

35. Anne, P.; Azzopardi, M.; Gissot, L.; Beaubiat, S.; Hématy, K.; Palauqui, J.-C. OCTOPUS Negatively Regulates BIN2 to Control Phloem Differentiation in Arabidopsis thaliana. Curr. Biol. 2015, 25, 2584-2590. [CrossRef] [PubMed]

36. Rodriguez-Villalon, A.; Gujas, B.; Kang, Y.H.; Breda, A.S.; Cattaneo, P.; Depuydt, S.; Hardtke, C.S. Molecular genetic framework for protophloem formation. Proc. Natl. Acad. Sci. USA 2014, 111, 11551-11556. [CrossRef] [PubMed]

37. Depuydt, S.; Rodriguez-Villalon, A.; Santuari, L.; Wyser-Rmili, C.; Ragni, L.; Hardtke, C.S. Suppression of Arabidopsis protophloem differentiation and root meristem growth by CLE45 requires the receptor-like kinase BAM3. Proc. Natl. Acad. Sci. USA 2013, 110, 7074-7079. [CrossRef] [PubMed]

38. Anne, P.; Amiguet-Vercher, A.; Brandt, B.; Kalmbach, L.; Geldner, N.; Hothorn, M.; Hardtke, C.S. CLERK is a novel receptor kinase required for sensing of root-active CLE peptides in Arabidopsis. Development 2018, 145. [CrossRef] 
39. Hazak, O.; Brandt, B.; Cattaneo, P.; Santiago, J.; Rodriguez-Villalon, A.; Hothorn, M.; Hardtke, C.S. Perception of root-active CLE peptides requires CORYNE function in the phloem vasculature. EMBO Rep. 2017, 18, 1367-1381. [CrossRef]

40. Kang, Y.H.; Hardtke, C.S. Arabidopsis MAKR5 is a positive effector of BAM3-dependent CLE45 signaling. EMBO Rep. 2016, 17, 1145-1154. [CrossRef]

41. Wallner, E.-S.; López-Salmerón, V.; Belevich, I.; Poschet, G.; Jung, I.; Grünwald, K.; Sevilem, I.; Jokitalo, E.; Hell, R.; Helariutta, Y.; et al. Strigolactone- and Karrikin-Independent SMXL Proteins Are Central Regulators of Phloem Formation. Curr. Biol. 2017, 27, 1241-1247. [CrossRef]

42. Salazar-Henao, J.E.; Lehner, R.; Betegón-Putze, I.; Vilarrasa-Blasi, J.; Caño-Delgado, A.I. BES1 regulates the localization of the brassinosteroid receptor BRL3 within the provascular tissue of the Arabidopsis primary root. J. Exp. Bot. 2016, 67, 4951-4961. [CrossRef] [PubMed]

43. Kang, Y.H.; Breda, A.; Hardtke, C.S. Brassinosteroid signaling directs formative cell divisions and protophloem differentiation in Arabidopsis root meristems. Development 2017, 144, 272-280. [CrossRef] [PubMed]

44. Marhava, P.; Bassukas, A.E.L.; Zourelidou, M.; Kolb, M.; Moret, B.; Fastner, A.; Schulze, W.X.; Cattaneo, P.; Hammes, U.Z.; Schwechheimer, C.; Hardtke, C.S. A molecular rheostat adjusts auxin flux to promote root protophloem differentiation. Nature 2018, 558, 297-300. [CrossRef]

45. Bonke, M.; Thitamadee, S.; Mähönen, A.P.; Hauser, M.-T.; Helariutta, Y. APL regulates vascular tissue identity in Arabidopsis. Nature 2003, 426, 181-186. [CrossRef] [PubMed]

46. Wisman, E.; Cardon, G.H.; Fransz, P.; Saedler, H. The behaviour of the autonomous maize transposable element En/Spm in Arabidopsis thaliana allows efficient mutagenesis. Plant Mol. Biol. 1998, 37, 989-999. [CrossRef] [PubMed]

47. Furuta, K.M.; Yadav, S.R.; Lehesranta, S.; Belevich, I.; Miyashima, S.; Heo, J.; Vatén, A.; Lindgren, O.; De Rybel, B.; Van Isterdael, G.; Somervuo, P.; Lichtenberger, R.; Rocha, R.; Thitamadee, S.; Tähtiharju, S.; Auvinen, P.; Beeckman, T.; Jokitalo, E.; Helariutta, Y. Plant development. Arabidopsis NAC45/86 direct sieve element morphogenesis culminating in enucleation. Science 2014, 345, 933-937. [CrossRef] [PubMed]

48. Kondo, Y.; Nurani, A.M.; Saito, C.; Ichihashi, Y.; Saito, M.; Yamazaki, K.; Mitsuda, N.; Ohme-Takagi, M.; Fukuda, H. Vascular Cell Induction Culture System Using Arabidopsis Leaves (VISUAL) Reveals the Sequential Differentiation of Sieve Element-Like Cells. Plant Cell 2016, 28, 1250-1262. [CrossRef]

49. Serrano-Mislata, A.; Sablowski, R. The pillars of land plants: new insights into stem development. Curr. Opin. Plant Biol. 2018, 45, 11-17. [CrossRef]

50. Evert, R.F. Esau's Plant Anatomy; John Wiley \& Sons, Inc.: Hoboken, NJ, USA, 2006; ISBN 9780470047385.

51. Ikematsu, S.; Tasaka, M.; Torii, K.U.; Uchida, N. ERECTA -family receptor kinase genes redundantly prevent premature progression of secondary growth in the Arabidopsis hypocotyl. New Phytol. 2017, 213, 1697-1709. [CrossRef]

52. Lehmann, F.; Hardtke, C.S. Secondary growth of the Arabidopsis hypocotyl-vascular development in dimensions. Curr. Opin. Plant Biol. 2016, 29, 9-15. [CrossRef]

53. Kuroha, T.; Ueguchi, C.; Sakakibara, H.; Satoh, S. Cytokinin receptors are required for normal development of auxin-transporting vascular tissues in the hypocotyl but not in the adventious roots. Plant Cell Physiol. 2006, 47, 234-243. [CrossRef] [PubMed]

54. Zhang, J.; Nieminen, K.; Serra, J.A.A.; Helariutta, Y. The formation of wood and its control. Curr. Opin. Plant Biol. 2014, 17, 56-63. [CrossRef] [PubMed]

55. Ragni, L.; Hardtke, C.S. Small but thick enough-the Arabidopsis hypocotyl as a model to study secondary growth. Physiol. Plant. 2014, 151, 164-171. [CrossRef] [PubMed]

56. Chaffey, N.; Cholewa, E.; Regan, S.; Sundberg, B. Secondary xylem development in Arabidopsis: a model for wood formation. Physiol. Plant. 2002, 114, 594-600. [CrossRef] [PubMed]

57. Sibout, R.; Plantegenet, S.; Hardtke, C.S. Flowering as a Condition for Xylem Expansion in Arabidopsis Hypocotyl and Root. Curr. Biol. 2008, 18, 458-463. [CrossRef]

58. Sankar, M.; Nieminen, K.; Ragni, L.; Xenarios, I.; Hardtke, C.S. Automated quantitative histology reveals vascular morphodynamics during Arabidopsis hypocotyl secondary growth. eLIFE 2014, 3, 1567. [CrossRef]

59. Ragni, L.; Nieminen, K.; Pacheco-Villalobos, D.; Sibout, R.; Schwechheimer, C.; Hardtke, C.S. Mobile gibberellin directly stimulates Arabidopsis hypocotyl xylem expansion. Plant Cell 2011, 23, 1322-1336. [CrossRef] 
60. Mitsuda, N.; Iwase, A.; Yamamoto, H.; Yoshida, M.; Seki, M.; Shinozaki, K.; Ohme-Takagi, M. NAC Transcription Factors, NST1 and NST3, Are Key Regulators of the Formation of Secondary Walls in Woody Tissues of Arabidopsis. Plant Cell. 2007, 19, 270-280. [CrossRef]

61. Kubo, M.; Udagawa, M.; Nishikubo, N.; Horiguchi, G.; Yamaguchi, M.; Ito, J.; Mimura, T.; Fukuda, H.; Demura, T. Transcription switches for protoxylem and metaxylem vessel formation. Genes Dev. 2005, 19, 1855-1860. [CrossRef]

62. Mele, G.; Ori, N.; Sato, Y.; Hake, S. The knotted1-like homeobox gene BREVIPEDICELLUS regulates cell differentiation by modulating metabolic pathways. Genes Dev. 2003, 17, 2088-2093. [CrossRef]

63. Liebsch, D.; Sunaryo, W.; Holmlund, M.; Norberg, M.; Zhang, J.; Hall, H.C.; Helizon, H.; Jin, X.; Helariutta, Y.; Nilsson, O.; Polle, A.; Fischer, U. Class I KNOX transcription factors promote differentiation of cambial derivatives into xylem fibers in the Arabidopsis hypocotyl. Development 2014, 141, 4311-4319. [CrossRef]

64. Lee, K.-H.; Avci, U.; Qi, L.; Wang, H. The $\alpha$ Aurora kinases function in vascular development in Arabidopsis. Plant Cell Physiol. 2018. [CrossRef] [PubMed]

65. Ito, Y.; Nakanomyo, I.; Motose, H.; Iwamoto, K.; Sawa, S.; Dohmae, N.; Fukuda, H. Dodeca-CLE peptides as suppressors of plant stem cell differentiation. Science 2006, 313, 842-845. [CrossRef] [PubMed]

66. Ji, J.; Strable, J.; Shimizu, R.; Koenig, D.; Sinha, N.; Scanlon, M.J. WOX4 Promotes Procambial Development 1. Plant Physiol. 2010, 152, 1346-1356. [CrossRef]

67. Etchells, J.P.; Provost, C.M.; Mishra, L.; Turner, S.R. WOX4 and WOX14 act downstream of the PXY receptor kinase to regulate plant vascular proliferation independently of any role in vascular organisation. Development 2013, 140, 2224-2234. [CrossRef]

68. Hirakawa, Y.; Kondo, Y.; Fukuda, H. TDIF peptide signaling regulates vascular stem cell proliferation via the WOX4 homeobox gene in Arabidopsis. Plant Cell 2010, 22, 2618-2629. [CrossRef]

69. Fisher, K.; Turner, S. PXY, a Receptor-like Kinase Essential for Maintaining Polarity during Plant Vascular-Tissue Development. Curr. Biol. 2007, 17, 1061-1066. [CrossRef] [PubMed]

70. Hirakawa, Y.; Shinohara, H.; Kondo, Y.; Inoue, A.; Nakanomyo, I.; Ogawa, M.; Sawa, S.; Ohashi-Ito, K.; Matsubayashi, Y.; Fukuda, H. Non-cell-autonomous control of vascular stem cell fate by a CLE peptide/receptor system. Proc. Natl. Acad. Sci. USA 2008, 105, 15208-15213. [CrossRef] [PubMed]

71. Etchells, J.P.; Provost, C.M.; Turner, S.R. Plant Vascular Cell Division Is Maintained by an Interaction between PXY and Ethylene Signalling. PLoS Genet. 2012, 8, e1002997. [CrossRef] [PubMed]

72. Agusti, J.; Lichtenberger, R.; Schwarz, M.; Nehlin, L.; Greb, T. Characterization of Transcriptome Remodeling during Cambium Formation Identifies MOL1 and RUL1 As Opposing Regulators of Secondary Growth. PLoS Genet. 2011, 7, e1001312. [CrossRef] [PubMed]

73. Gursanscky, N.R.; Jouannet, V.; Grünwald, K.; Sanchez, P.; Laaber-Schwarz, M.; Greb, T. MOL1 is required for cambium homeostasis in Arabidopsis. Plant J. 2016, 86, 210-220. [CrossRef] [PubMed]

74. Suer, S.; Agusti, J.; Sanchez, P.; Schwarz, M.; Greb, T. WOX4 imparts auxin responsiveness to cambium cells in Arabidopsis. Plant Cell 2011, 23, 3247-3259. [CrossRef] [PubMed]

75. Denis, E.; Kbiri, N.; Mary, V.; Claisse, G.; Conde e Silva, N.; Kreis, M.; Deveaux, Y. WOX14 promotes bioactive gibberellin synthesis and vascular cell differentiation in Arabidopsis. Plant J. 2017, 90, 560-572. [CrossRef] [PubMed]

76. Wang, N.; Bagdassarian, K.S.; Doherty, R.; Wang, X.; Kroon, J.; Wang, W.; Jermyn, I.; Turner, S.; Etchells, P. Paralogues of the PXY and ER receptor kinases enforce radial patterning in plant vascular tissue. bioRxiv 2018, 357244. [CrossRef]

77. Agusti, J.; Herold, S.; Schwarz, M.; Sanchez, P.; Ljung, K.; Dun, E.A.; Brewer, P.B.; Beveridge, C.A.; Sieberer, T.; Sehr, E.M.; Greb, T. Strigolactone signaling is required for auxin-dependent stimulation of secondary growth in plants. Proc. Natl. Acad. Sci. USA 2011, 108, 20242-20247. [CrossRef] [PubMed]

78. Sehr, E.M.; Agusti, J.; Lehner, R.; Farmer, E.E.; Schwarz, M.; Greb, T. Analysis of secondary growth in the Arabidopsis shoot reveals a positive role of jasmonate signalling in cambium formation. Plant J. 2010, 63, 811-822. [CrossRef] [PubMed]

79. Matsumoto-Kitano, M.; Kusumoto, T.; Tarkowski, P.; Kinoshita-Tsujimura, K.; Václavíková, K.; Miyawaki, K.; Kakimoto, T. Cytokinins are central regulators of cambial activity. Proc. Natl. Acad. Sci. USA 2008, 105, 20027-20031. [CrossRef]

80. Oles, V.; Panchenko, A.; Smertenko, A. Modeling hormonal control of cambium proliferation. PLoS One 2017, 12, e0171927. [CrossRef] 
81. Han, S.; Cho, H.; Noh, J.; Qi, J.; Jung, H.-J.; Nam, H.; Lee, S.; Hwang, D.; Greb, T.; Hwang, I. BIL1-mediated MP phosphorylation integrates PXY and cytokinin signalling in secondary growth. Nat. Plants 2018, 4, 605-614. [CrossRef] [PubMed]

82. Brackmann, K.; Qi, J.; Gebert, M.; Jouannet, V.; Schlamp, T.; Grünwald, K.; Wallner, E.-S.; Novikova, D.D.; Levitsky, V.G.; Agustí, J.; Sanchez, P.; Lohmann, J.U.; Greb, T. Spatial specificity of auxin responses coordinates wood formation. Nat. Commun. 2018, 9, 875. [CrossRef]

83. Kondo, Y.; Ito, T.; Nakagami, H.; Hirakawa, Y.; Saito, M.; Tamaki, T.; Shirasu, K.; Fukuda, H. Plant GSK3 proteins regulate xylem cell differentiation downstream of TDIF-TDR signalling. Nat. Commun. 2014, 5, 3504. [CrossRef] [PubMed]

84. Ilegems, M.; Douet, V.; Meylan-Bettex, M.; Uyttewaal, M.; Brand, L.; Bowman, J.L.; Stieger, P.A. Interplay of auxin, KANADI and Class III HD-ZIP transcription factors in vascular tissue formation. Development 2010, 137, 975-984. [CrossRef] [PubMed]

85. Cho, H.; Cho, H.S.; Nam, H.; Jo, H.; Yoon, J.; Park, C.; Dang, T.V.T.; Kim, E.; Jeong, J.; Park, S.; et al. Translational control of phloem development by RNA G-quadruplex-JULGI determines plant sink strength. Nat. Plants 2018, 4, 376-390. [CrossRef] [PubMed]

86. Randall, R.S.; Miyashima, S.; Blomster, T.; Zhang, J.; Elo, A.; Karlberg, A.; Immanen, J.; Nieminen, K.; Lee, J.-Y.; Kakimoto, T.; et al. AINTEGUMENTA and the D-type cyclin CYCD3;1 regulate root secondary growth and respond to cytokinins. Biol. Open 2015, 4, 1229-1236. [CrossRef] [PubMed]

87. Uchida, N.; Lee, J.S.; Horst, R.J.; Lai, H.-H.; Katjita, R.; Kakimoto, T.; Tasaka, M.; Torii, K.U. Regulation of inflorescence architecture by intertissue layer ligand-receptor communication between endodermis and ploem. PNAS 2012, 109, 6337-6342. [CrossRef] [PubMed]

88. Eriksson, M.E.; Israelsson, M.; Olsson, O.; Moritz, T. Increased gibberellin biosynthesis in transgenic trees promotes growth, biomass production and xylem fiber length. Nat. Biotechnol. 2000, 18, 784-788. [CrossRef] [PubMed]

89. Nieminen, K.; Immanen, J.; Laxell, M.; Kauppinen, L.; Tarkowski, P.; Dolezal, K.; Tahtiharju, S.; Elo, A.; Decourteix, M.; Ljung, K.; et al. Cytokinin signaling regulates cambial development in poplar. Proc. Natl. Acad. Sci. 2008, 105, 20032-20037. [CrossRef] [PubMed]

90. Nilsson, J.; Karlberg, A.; Antti, H.; Lopez-Vernaza, M.; Mellerowicz, E.; Perrot-Rechenmann, C.; Sandberg, G.; Bhalerao, R.P. Dissecting the Molecular Basis of the Regulation of Wood Formation by Auxin in Hybrid Aspen. Plant Cell Online 2008, 20, 843-855. [CrossRef] [PubMed]

91. Love, J.; Bjorklund, S.; Vahala, J.; Hertzberg, M.; Kangasjarvi, J.; Sundberg, B. Ethylene is an endogenous stimulator of cell division in the cambial meristem of Populus. Proc. Natl. Acad. Sci. USA 2009, 106, 5984-5989. [CrossRef]

92. Du, J.; Miura, E.; Robischon, M.; Martinez, C.; Groover, A. The Populus Class III HD ZIP Transcription Factor POPCORONA Affects Cell Differentiation during Secondary Growth of Woody Stems. PLoS One 2011, 6, e17458. [CrossRef]

93. Etchells, J.P.; Mishra, L.S.; Kumar, M.; Campbell, L.; Turner, S.R. Wood Formation in Trees Is Increased by Manipulating PXY-Regulated Cell Division. Curr. Biol. 2015, 25, 1050-1055. [CrossRef] [PubMed]

94. Kucukoglu, M.; Nilsson, J.; Zheng, B.; Chaabouni, S.; Nilsson, O. WUSCHEL-RELATED HOMEOBOX4 (WOX4) -like genes regulate cambial cell division activity and secondary growth in Populus trees. New Phytol. 2017, 215, 642-657. [CrossRef] [PubMed]

95. Ramachandran, P.; Carlsbecker, A.; Etchells, J.P. Class III HD-ZIPs govern vascular cell fate: an HD view on patterning and differentiation. J. Exp. Bot. 2017, 68, 55-69. [CrossRef] [PubMed]

96. Nieminen, K.; Blomster, T.; Helariutta, Y.; Mähönen, A.P. Vascular Cambium Development. Arab. B. 2015, 13, e0177. [CrossRef] [PubMed]

97. Ragni, L.; Greb, T. Secondary growth as a determinant of plant shape and form. Semin. Cell Dev. Biol. 2018, 79, 58-67. [CrossRef] [PubMed]

98. Bhalerao, R.P.; Fischer, U. Environmental and hormonal control of cambial stem cell dynamics. J. Exp. Bot. 2017, 68, 79-87. [CrossRef] [PubMed]

99. Bossinger, G.; Spokevicius, A. V Sector analysis reveals patterns of cambium differentiation in poplar stems. J. Exp. Bot. 2018, 69, 4339-4348. [CrossRef] 
100. Petzold, H.E.; Rigoulot, S.B.; Zhao, C.; Chanda, B.; Sheng, X.; Zhao, M.; Jia, X.; Dickerman, A.W.; Beers, E.P.; Brunner, A.M. Identification of new protein-protein and protein-DNA interactions linked with wood formation in Populus trichocarpa. Tree Physiol. 2018, 38, 362-377. [CrossRef]

101. Petzold, H.E.; Chanda, B.; Zhao, C.; Rigoulot, S.B.; Beers, E.P.; Brunner, A.M. DIVARICATA AND RADIALIS INTERACTING FACTOR (DRIF) also interacts with WOX and KNOX proteins associated with wood formation in Populus trichocarpa. Plant J. 2018, 93, 1076-1087. [CrossRef]

102. Immanen, J.; Nieminen, K.; Smolander, O.-P.; Kojima, M.; Alonso Serra, J.; Koskinen, P.; Zhang, J.; Elo, A.; Mähönen, A.P.; Street, N.; et al. Cytokinin and Auxin Display Distinct but Interconnected Distribution and Signaling Profiles to Stimulate Cambial Activity. Curr. Biol. 2016, 26, 1990-1997. [CrossRef]

103. Obudulu, O.; Bygdell, J.; Sundberg, B.; Moritz, T.; Hvidsten, T.R.; Trygg, J.; Wingsle, G. Quantitative proteomics reveals protein profiles underlying major transitions in aspen wood development. BMC Genomics 2016, 17, 119. [CrossRef] [PubMed]

104. Sundell, D.; Street, N.R.; Kumar, M.; Mellerowicz, E.J.; Kucukoglu, M.; Johnsson, C.; Kumar, V.; Mannapperuma, C.; Delhomme, N.; Nilsson, O.; et al. AspWood: High-Spatial-Resolution Transcriptome Profiles Reveal Uncharacterized Modularity of Wood Formation in Populus tremula. Plant Cell. 2017, 29, 1585-1604. [CrossRef]

105. Jin, F.; Li, J.; Ding, Q.; Wang, Q.-S.; He, X.-Q. Proteomic analysis provides insights into changes in the central metabolism of the cambium during dormancy release in poplar. J. Plant Physiol. 2017, 208, 26-39. [CrossRef] [PubMed]

106. Jang, G.; Lee, J.-H.; Rastogi, K.; Park, S.; Oh, S.-H.; Lee, J.-Y. Cytokinin-dependent secondary growth determines root biomass in radish (Raphanus sativus L.). J. Exp. Bot. 2015, 66, 4607-4619. [CrossRef] [PubMed]

107. R R̊žička, K.; Ursache, R.; Hejátko, J.; Helariutta, Y. Xylem development - from the cradle to the grave. New Phytol. 2015, 207, 519-535. [CrossRef] [PubMed]

108. Kumar, M.; Campbell, L.; Turner, S. Secondary cell walls: biosynthesis and manipulation. J. Exp. Bot. 2016, 67, 515-531. [CrossRef]

109. Meents, M.J.; Watanabe, Y.; Samuels, A.L. The cell biology of secondary cell wall biosynthesis. Ann. Bot. 2018, 121, 1107-1125. [CrossRef]

110. Spicer, R. Variation in Angiosperm Wood Structure and Its Physiological and Evolutionary Significance. In Comparative and Evolutionary Genomics of Angiosperm Trees; Springer: Cham, Switzerland, 2016; pp. $19-60$.

111. Lens, F.; Picon-Cochard, C.; Delmas, C.E.L.; Signarbieux, C.; Buttler, A.; Cochard, H.; Jansen, S.; Chauvin, T.; Doria, L.C.; Del Arco, M.; et al. Herbaceous Angiosperms Are Not More Vulnerable to Drought-Induced Embolism Than Angiosperm Trees. Plant Physiol. 2016, 172, 661-667. [CrossRef]

112. Pereira, L.; Domingues-Junior, A.P.; Jansen, S.; Choat, B.; Mazzafera, P. Is embolism resistance in plant xylem associated with quantity and characteristics of lignin? Trees 2018, 32, 349-358. [CrossRef]

113. Johnson, D.; Eckart, P.; Alsamadisi, N.; Noble, H.; Martin, C.; Spicer, R. Polar auxin transport is implicated in vessel differentiation and spatial patterning during secondary growth in Populus. Am. J. Bot. 2018, 105, 186-196. [CrossRef]

114. Morris, H.; Plavcov, L.; Cvecko, P.; Fichtler, E.; Gillingham, M.A.F.; Mart Inez-Cabrera, H.I.; Mcglinn, D.J.; Wheeler, E.; Zheng, J.; Ziemi Nska, K.; et al. A global analysis of parenchyma tissue fractions in secondary xylem of seed plants. New Phytol. 2016, 209, 1553-1565. [CrossRef] [PubMed]

115. Mazur, E.; Kurczynska, E.U. Rays, intrusive growth, and storied cambium in the inflorescence stems of Arabidopsis thaliana (L.) Heynh. Protoplasma 2012, 249, 217-220. [CrossRef] [PubMed]

116. Ramage, M.H.; Burridge, H.; Busse-Wicher, M.; Fereday, G.; Reynolds, T.; Shah, D.U.; Wu, G.; Yu, L.; Fleming, P.; Densley-Tingley, D.; et al. The wood from the trees: The use of timber in construction. Renew. Sustain. Energy Rev. 2017, 68, 333-359. [CrossRef]

117. Song, J.; Chen, C.; Zhu, S.; Zhu, M.; Dai, J.; Ray, U.; Li, Y.; Kuang, Y.; Li, Y.; Quispe, N.; et al. Processing bulk natural wood into a high-performance structural material. Nature 2018, 554, 224-228. [CrossRef]

118. Groover, A. Gravitropisms and reaction woods of forest trees - evolution, functions and mechanisms. New Phytol. 2016, 211, 790-802. [CrossRef]

119. Navarro, C.; Cruz-Oró, E.; Prat, S. Conserved function of FLOWERING LOCUS T (FT) homologues as signals for storage organ differentiation. Curr. Opin. Plant Biol. 2015, 23, 45-53. [CrossRef] [PubMed] 
120. Yu, R.; Wang, J.; Xu, L.; Wang, Y.; Wang, R.; Zhu, X.; Sun, X.; Luo, X.; Xie, Y.; Everlyne, M.; Liu, L. Transcriptome Profiling of Taproot Reveals Complex Regulatory Networks during Taproot Thickening in Radish (Raphanus sativus L.). Front. Plant Sci. 2016, 7, 1210. [CrossRef] [PubMed]

121. Benjamin, L.R.; Wren, M.J. Root Development and Source-Sink Relations in Carrot, Daucus carota L. J. Exp. Bot. 1978, 29, 425-433. [CrossRef]

122. Tanaka, M. Recent Progress in Molecular Studies on Storage Root Formation in Sweetpotato (Ipomoea batatas). Biotechnology 2016, 50, 293-299. [CrossRef]

123. El-Sharkawy, M.A. Cassava biology and physiology. Plant Mol. Biol. 2004, 56, 481-501. [CrossRef] [PubMed]

124. Wang, G.-L.; Xiong, F.; Que, F.; Xu, Z.-S.; Wang, F.; Xiong, A.-S. Morphological characteristics, anatomical structure and gene expression: novel insights into gibberellin biosynthesis and perception during carrot growth and development. Hortic. Res. 2015, 2, 15028. [CrossRef]

125. Mitsui, Y.; Shimomura, M.; Komatsu, K.; Namiki, N.; Shibata-Hatta, M.; Imai, M.; Katayose, Y.; Mukai, Y.; Kanamori, H.; Kurita, K.; et al. The radish genome and comprehensive gene expression profile of tuberous root formation and development. Sci. Rep. 2015, 5, 10835. [CrossRef]

126. Chaweewan, Y.; Taylor, N. Anatomical Assessment of Root Formation and Tuberization in Cassava (Manihot esculenta Crantz). Trop. Plant Biol. 2015, 8, 1-8. [CrossRef]

127. Akoumianakis, K.A.; Alexopoulos, A.A.; Karapanos, I.C.; Kalatzopoulos, K.; Aivalakis, G.; Passam, H.C. Carbohydrate metabolism and tissue differentiation during potato tuber initiation, growth and dormancy induction. Aust. J. Crop Sci. 2016, 10, 185-192.

128. Firon, N.; LaBonte, D.; Villordon, A.; Kfir, Y.; Solis, J.; Lapis, E.; Perlman, T.S.; Doron-Faigenboim, A.; Hetzroni, A.; Althan, L.; et al. Transcriptional profiling of sweetpotato (Ipomoea batatas) roots indicates down-regulation of lignin biosynthesis and up-regulation of starch biosynthesis at an early stage of storage root formation. BMC Genomics 2013, 14, 460. [CrossRef]

129. Noh, S.A.; Lee, H.-S.; Huh, E.J.; Huh, G.H.; Paek, K.-H.; Shin, J.S.; Bae, J.M. SRD1 is involved in the auxin-mediated initial thickening growth of storage root by enhancing proliferation of metaxylem and cambium cells in sweetpotato (Ipomoea batatas). J. Exp. Bot. 2010, 61, 1337-1349. [CrossRef]

130. Zhang, N.; Zhao, J.; Lens, F.; de Visser, J.; Menamo, T.; Fang, W.; Xiao, D.; Bucher, J.; Basnet, R.K.; Lin, K.; et al. Morphology, carbohydrate composition and vernalization response in a genetically diverse collection of Asian and European turnips (Brassica rapa subsp. rapa). PLoS One 2014, 9, e114241. [CrossRef]

131. Wang, G.-L.; Que, F.; Xu, Z.-S.; Wang, F.; Xiong, A.-S. Exogenous gibberellin enhances secondary xylem development and lignification in carrot taproot. Protoplasma 2017, 254, 839-848. [CrossRef]

132. Eviatar-Ribak, T.; Shalit-Kaneh, A.; Chappell-Maor, L.; Amsellem, Z.; Eshed, Y.; Lifschitz, E. Article A Cytokinin-Activating Enzyme Promotes Tuber Formation in Tomato. Curr. Biol. 2013, 23, 1057-1064. [CrossRef]

133. Gancheva, M.S.; Dodueva, I.E.; Lebedeva, M.A.; Tvorogova, V.E.; Tkachenko, A.A.; Lutova, L.A. Identification, expression, and functional analysis of CLE genes in radish (Raphanus sativus L.) storage root. BMC Plant Biol. 2016, 16, 7. [CrossRef]

134. Wang, G.-L.; Que, F.; Xu, Z.-S.; Wang, F.; Xiong, A.-S. Exogenous gibberellin altered morphology, anatomic and transcriptional regulatory networks of hormones in carrot root and shoot. BMC Plant Biol. 2015, 15, 290. [CrossRef]

135. Jabir, B.M.; Kinuthia Karanja, B.; Almahadi Faroug, M.; Nureldin Awad, F. Effects of Gibberellin and Gibberellin Biosynthesis Inhibitor (Paclobutrazol) Applications on Radish (Raphanus sativus L.) Taproot Expansion and the Presence of Authentic Hormones. Artic. Int. J. Agric. Biol. 2017, 19, 779-786. [CrossRef]

136. Mabvongwe, O.; Manenji, B.T.; Gwazane, M.; Chandiposha, M. The Effect of Paclobutrazol Application Time and Variety on Growth, Yield, and Quality of Potato (Solanum tuberosum L.). Adv. Agric. 2016, 2016, 1-5. [CrossRef]

137. Yang, J.; An, D.; Zhang, P. Expression Profiling of Cassava Storage Roots Reveals an Active Process of Glycolysis/Gluconeogenesis. J. Integr. Plant Biol. 2011, 53, 193-211. [CrossRef]

(C) 2018 by the authors. Licensee MDPI, Basel, Switzerland. This article is an open access article distributed under the terms and conditions of the Creative Commons Attribution (CC BY) license (http://creativecommons.org/licenses/by/4.0/). 